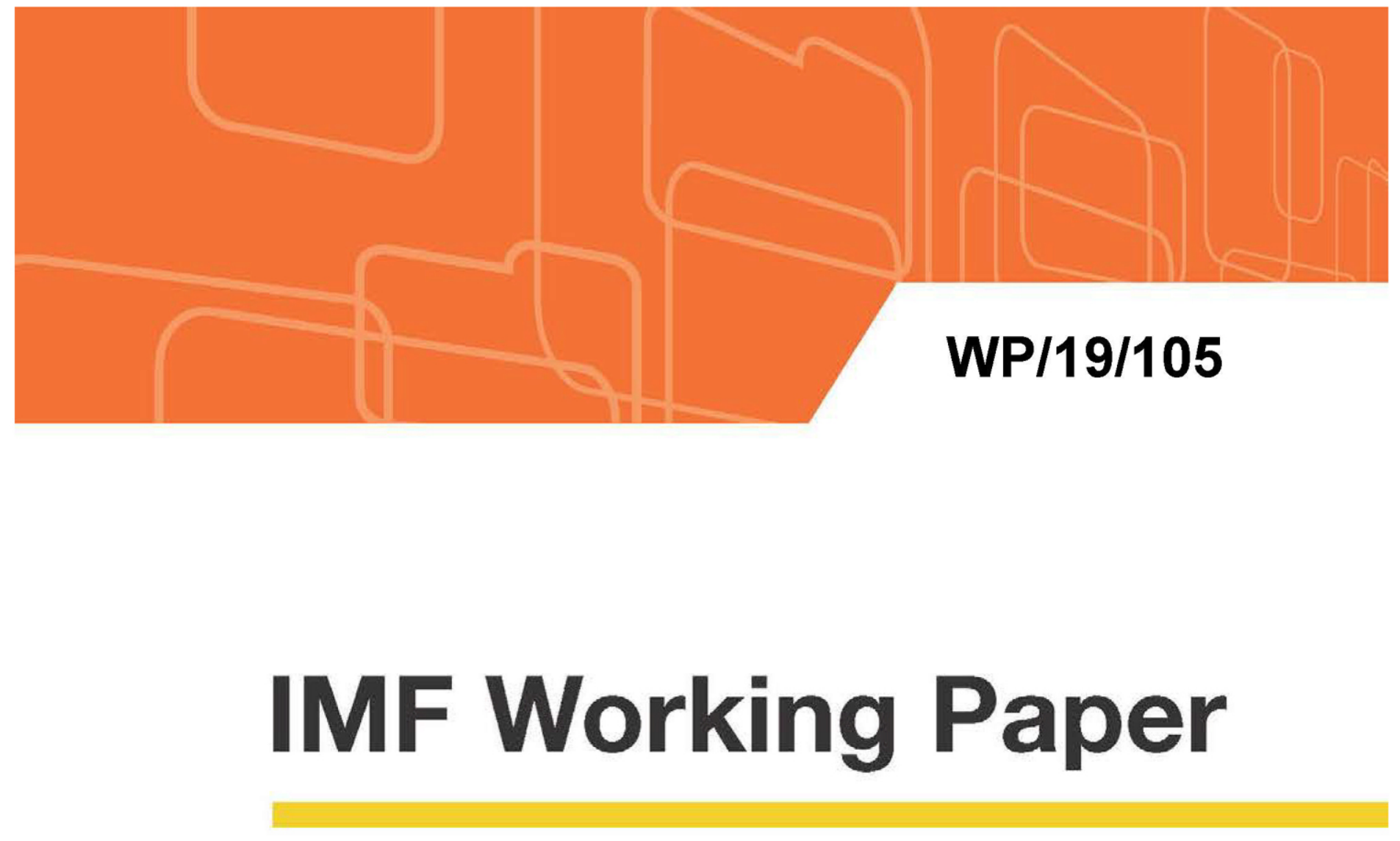

\title{
Understanding Export Diversification: Key Drivers and Policy Implications
}

By Rahul Giri, Saad Noor Quayyum, Rujun Joy Yin

IMF Working Papers describe research in progress by the author(s) and are published to elicit comments and to encourage debate. The views expressed in IMF Working Papers are those of the author(s) and do not necessarily represent the views of the IMF, its Executive Board, or IMF management. 


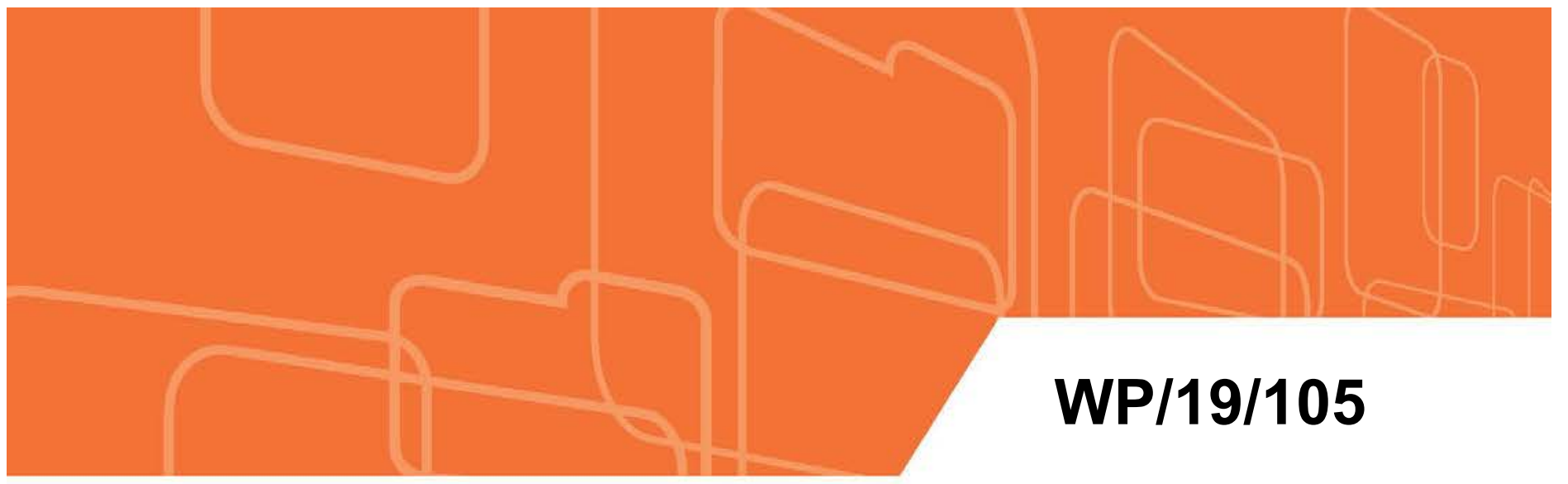

\section{IMF Working Paper}

\section{Understanding Export Diversification: Key Drivers and Policy Implications}

By Rahul Giri, Saad Noor Quayyum, Rujun Joy Yin

IMF Working Papers describe research in progress by the author(s) and are published to elicit comments and to encourage debate. The views expressed in IMF Working Papers are those of the author(s) and do not necessarily represent the views of the IMF, its Executive Board, or IMF management.

I N T E R N A T I O N A L M O N E T A R Y F U N D 


\title{
IMF Working Paper
}

Strategy, Policy and Review Department

\section{Understanding Export Diversification: Key Drivers and Policy Implications \\ Prepared by Rahul Giri, Saad Quayyum and Rujun Yin ${ }^{1}$}

Authorized for distribution by Johannes Wiegand

May 2019

\section{IMF Working Papers describe research in progress by the author(s) and are published to elicit comments and to encourage debate. The views expressed in IMF Working Papers are those of the author(s) and do not necessarily represent the views of the IMF, its Executive Board, or IMF management.}

\begin{abstract}
We identify key factors, from large set of potential determinants, that explain the variation in export diversification across countries and over time using Bayesian Model Averaging (BMA), which addresses model uncertainty and ranks factors in order of importance vis-avis their explanatory power. Our analysis suggests, in order to diversify, policy makers should prioritize human capital accumulation and reduce barriers to trade. Other policy areas include improving quality of institutions and developing the financial sector. For commodity exporters reducing barriers to trade is the most important driver of diversification, followed by improving education outcomes at the secondary level and financial sector development.
\end{abstract}

JEL Classification Numbers: [C33;F63;O19;055]

Keywords: Diversification, Education, Trade, Natural Resource Rent, Commodity Exporter Authors’ E-Mail Addresses: rgiri@imf.org, squayyum@,imf.org, ryin@,imf.org1

\footnotetext{
${ }^{1}$ The authors are grateful to Reda Cherif, Stefania Fabrizio, Narita Futsohi, Roland Kpodar, Vladimir Klyuev, Ali Mansoor, Sean Nolan, Nikola Spatafora, and Development Issues Unit's open forum participants for helpful comments and suggestions. The research is part of a Macroeconomic Research in Low-Income Countries project supported by the UK Department for International Development (DFID).
} 
I. INTRODUCTION

II. RELATED LITERATURE

III. METHODOLOGY AND DATA $\underline{8}$

IV. STYLIZED FACTS $\underline{10}$

V. DRIVERS OF EXPORT DIVERSIFICATION: ALL COUNTRIES AND EMDES 14

VI. DRIVERS OF EXPORT DIVERSIFICATION: EMDE COMMODITY EXPORTERS VERSUS DIVERSIFIED EXPORTERS

VII. DOING BUSINESS INDICATORS AND DIVERSIFICATION

VIII. POLICY IMPLICATIONS

IX. CONCLUSION

References $\underline{23}$

\section{FIGURES}

1. Diversification and Development

2. Diversification and Potential Determinants $\underline{11}$

3. Diversification and Potential Determinants

\section{TABLES}

1. Distribution Statistics of Diversification Index 10

2. Baseline Specification, All Countries and EMDEs $\underline{27}$

3. Baseline Specification, EMDEs - Commodity and Diversified Exporters $\underline{28}$

4. Baseline Specification with Doing Business Indicator $\underline{29}$ 


\section{INTRODUCTION}

There is a strong interest among policy makers in understanding and achieving diversification in low and middle-income countries. This is especially true for commodity exporters, who are highly susceptible to commodity price fluctuations, and who face significant macroeconomic challenges and struggle to grow in low commodity price environment. In addition, with natural resources wealth likely to run out in the future many commodity exporters are often hard pressed to find an alternative engine of growth.

Conceptually, the objective of diversification appears to go against the benefits of specialization driven by comparative advantage, which is the cornerstone of trade theory. However, greater openness to trade and specialization increase exposure to sector-specific external shocks which may be difficult to insure against. Diversification, therefore, can help to reduce macroeconomic volatility and empirical evidence shows that this is indeed the case (IMF (2014), Haddad et al. (2013), and Koren and Tenreyro (2007)). Moreover, there is evidence that diversification can support growth in low income countries. IMF (2014) and IMF (2017), which focused on making a case for diversification, find that diversification in both exports and output is a key determinant of growth for low-income countries (LICs).

In this paper we build on Cadot et al. (2011b), IMF (2014) and IMF (2017). First, like Cadot et al (2011b), we focus on the drivers of diversification, but identify the key factors robustly associated with export diversification from a much larger set of potential drivers. ${ }^{2}$ Second, we put a lens on export diversification in resource rich developing economies, something not explored in the three aforementioned studies; as emphasized above the need for and benefit from diversification is potentially the greatest in such economies. Third, given the potentially large set of factors that can affect diversification and the lack of consensus on the channels through which these effects get transmitted, we use Bayesian Model Averaging (BMA) to address model uncertainty. Importantly, the BMA approach also ranks variables in order of importance vis-a-vis their explanatory power. IMF (2014) and IMF (2017) also employ BMA in a growth regression framework.

The BMA analysis highlights some key factors that, expectedly, predispose countries toward lower export diversification - size of the economy and natural resource abundance. Smaller and resource abundant countries tend to be less diversified. However, resource abundance impedes diversification not only at the intensive margin - distribution of export earnings across a fixed set of products -, but more importantly also at the extensive margin - change in distribution of export earnings due to (net) addition of products. In other words, even among the commodity exporters, countries with higher natural resource rents are likely to export fewer products after controlling for other factors, including quality of institutions. The

\footnotetext{
${ }^{2}$ IMF (2014) analyzed diversification more broadly from a structural change perspective and not just from a perspective of export diversification.
} 
negative effect on the extensive margin is akin to the Dutch disease effect of resources on growth discussed in the context of the literature on the resource curse.

Among the set of actionable policy areas, BMA reveals the following to be most robustly associated (in order of importance vis-a-vis their explanatory power) with higher export diversification: (i) higher levels of human capital, with primary education being the key driver via the extensive margin, but secondary education being more important in commodity exporters mainly through the extensive margin; (ii) greater openness to trade especially through the extensive margin; and (iii) higher quality institutions, proxied by quality of governance.

In addition, we find that more developed financial sector can help diversification, especially among commodity exporters, at the intensive margin; better infrastructure, measured by phone connectivity, is associated with higher diversification through the extensive margin, but this association is weak among commodity exporters; and greater openness to capital flows also helps diversification by positively affecting the intensive margin of diversification, but not among commodity exporters.

We also augment our baseline set of macro variables, with World Bank's Doing Business indicators. However, this comes at the cost of reducing the sample size due to a shorter time series availability of these indicators. With the truncated sample, we find that lower costs of trading across borders are associated with greater diversification.

The rest of the paper is organized as follows. Section II reviews the related literature, section III discusses the data and methodology, section IV presents some stylized facts, Sections V and VI discuss the results on the drivers of diversification for all countries and commodity exporters, respectively, section VII presents the results with Doing Business indicators, and section VIII draws policy lessons from the analysis. The last section concludes.

\section{RELATED LiteratuRE}

The process of economic development involves sustained growth in GDP per capita along with structural change, where the latter refers to the reallocation of factors of production and output across different activities or sectors. Most of the literature has investigated structural change at an aggregate level, which typically entails reallocation from agriculture to industry and then to services (see Herrendorf et al. (2014) for an exhaustive review). ${ }^{3}$

While this aggregate analysis of structural transformation is encompassed in the concept of diversification, it was the seminal work of Imbs and Wacziarg (2003) (IW henceforth) that analyzed the process of reallocation of output and labor along the development path at a more granular level - cross-country data across 9 broad sectors as well as 28 manufacturing

\footnotetext{
${ }^{3}$ Some developing economies are departing from this traditional path and are experiencing a shift from agriculture to services without much industrialization (Rodrik (2016), Diao et al. (2017)).
} 
industries. They found that there exist "stages of diversification" along the development path, which refers to the U-shaped relationship between specialization and income - starting with low levels of income countries diversify as their income rises, and then start reconcentrating/specializing once they reach the income level of upper-middle income and advanced-economies. This was later corroborated by Klinger and Lederman (2006) and Cadot et al. (2011a) for diversification across export products, with the latter using highly disaggregated export data. ${ }^{4}$ Focusing on introduction of new export products - extensive margin of exports -, both studies find that diversification in poor countries is mostly due to the extensive margin. IMF (2014) also finds evidence for this among the LICs, with a broader move from agriculture to manufacturing exports. ${ }^{5}$

IW interpret the stages of diversification through the lens of a Ricardian trade model, where an interaction of rising productivity (increases the range of goods produced) and declining trade costs (increases concentration) delivers the U-shaped relationship between diversification and income. One such combination is where closing the technological gap becomes increasingly difficult, but trade costs decline linearly. Klinger and Lederman (2006), on the other hand, emphasize the importance of market failures in new product discoveries, as put forth by Hausman and Rodrik (2003), which suggests that successful new product discoveries create valuable social knowledge. However, this type of innovation cannot be protected from imitation, and hence entrepreneurs will underinvest in the experimentation necessary to discover new export opportunities, causing the process of productive diversification to stagnate. More recently, Samaniego and Sun (2016) develop a multi-sector closed economy model in which different productivity growth rates across industries and sectors lead to structural transformation as well as the U-shaped diversification pattern in a closed economy setting. ${ }^{6}$

IMF (2014) (as well as IMF (2017)) does not take a stand on the mechanism(s) behind the process of diversification. Instead it focused on making an empirical case for diversification by providing evidence for a causal effect of diversification on growth in LICs. Given the multiplicity of potential mechanism affecting diversification and the resulting uncertainty in model specification, we adopt the BMA methodology used in IMF (2014). ${ }^{7}$ It allows us to

\footnotetext{
${ }^{4}$ They used 6-digit HS (harmonized system) product level data on exports, yielding 4,991 products.

${ }^{5}$ Furthermore, IMF (2014) shows that while developing countries in East Asia and Pacific have steadily improved the quality of their exports, Sub-Saharan African (SSA) countries have seen a steady decline in quality of their exports.

${ }^{6}$ There are three sectors - agriculture, manufacturing and services -, and industries within the manufacturing sector. Goods of three sectors are compliments, but goods of industries within manufacturing are substitutes.

${ }^{7}$ See Rockey and Temple (2016) for a review of the use of BMA in the growth literature.
} 
parse through the potentially numerous proximate determinants of diversification, and ranks them based on a posterior inclusion probability.

We go beyond the link between diversification and income and explore a much richer set of determinants of diversification than existing papers (including Cadot et al. (2011b), IMF 2017), which includes the following country features - size, resource wealth, trade, market access, trade costs, FDI, human capital, public investment and expenditure, exchange rate misalignment, terms of trade, financial market development, infrastructure, and quality of institutions. Furthermore, we also bring in information from Doing Business Indicators into our analysis, which has not been examined so far in the literature.

The paper also contributes by focusing specifically on resource dependent economies, which are exposed to commodity price fluctuations, and have struggled to diversify away from natural resource dependent industries. Though IMF (2014) excludes commodity exporters from its analysis of diversification among LICs, it documents that commodity exporters tend to be less diversified, have lower quality exports and larger agricultural employment as compared to diversified exporters.

The literature on resource dependence has focused on the link between resource abundance and growth. It found that resource rich economies experienced slower growth, which came to be known as the natural resource curse - Auty (1993), Sachs and Warner (1995), Sala-iMartin and Subhramanian (2003) and Kaldor, Karl and Said (2007). However, recent evidence questions the presence of a curse. Resource wealth can create incentives to block institutional development and thereby prevent checks and balances on excessive rent seeking - Collier and Hoefler (2009), Bulte and Damania (2008), Caselli and Cunningham (2009). Brunnschweiler and Bulte (2008) argue that measuring natural resource dependence by the share of primary products in either total exports or in GDP makes it endogenous to bad policies and institutional breakdowns. The intuition is that resource sectors are well protected enclaves that survive institutional breakdowns whereas manufacturing doesn't, and hence bad policies and poor institutions can mechanically raise the importance of the resource sector while also causing poor subsequent growth. We explore the importance of various factors that are important for diversification among commodity exporters, including size of resource rents, rate of resource depletion, quality of institution, change in terms of trade and exchange rate overvaluation.

Our paper attempts to shed light on the question: how should a country try to diversify? Callen et al. (2014) finds that improving incentive structure for workers and firms is key to diversification in the Gulf countries. Cherif et al. (2016) notes the importance of industrial policy to develop and diversify the economy. Our paper does not delve into labor market reforms or industrial policy due to data limitations. 


\section{Methodology ANd Data}

The diversification index of a country is a Theil index following Cadot et al. (2011a) and calculated as follows for each year:

$$
D_{i}=\frac{1}{n} \sum_{k=1}^{n} \frac{x_{i k}}{\mu} \cdot \ln \left(\frac{x_{i k}}{\mu}\right)
$$

where $x_{i k}$ is the value of product $k$ exported by country $i, n$ is the total number of export products, and $\mu$ is average exports defined as

$$
\mu=\frac{1}{n} \sum_{k=1}^{n} x_{k}
$$

A desirable property of the Theil index is that it can be decomposed into a between group $\left(D_{i, \text { between }}\right)$ and a within group $\left(D_{i, \text { within }}\right)$ component.

$$
D_{i}=\underbrace{\sum_{j=0}^{J} \frac{n_{j}}{n} \frac{\mu_{i j}}{\mu} \ln \left(\frac{\mu_{i j}}{\mu}\right)}_{D_{i, \text { between }}}+\underbrace{\sum_{j=1}^{J} \frac{n_{j}}{n} \frac{\mu_{i j}}{\mu}\left[\frac{1}{n_{j}} \sum_{k \in G_{j}}^{N} \frac{x_{i k}}{\mu_{j}} \cdot \ln \left(\frac{x_{i k}}{\mu_{j}}\right)\right]}_{D_{i, \text { within }}},
$$

where $j=1, \ldots, J$ represents $J$ partitions or groups of export products, $n_{j}$ is the number of products and $\mu_{j}$ is the average export value in group $j$. Note that the term in the big parenthesis on the right-hand side of the equation above is the Theil index for group $j$. The between group component captures diversification resulting from the extensive margin of trade, i.e. net addition of exported products. The within group component captures diversification due to a more even distribution of export sales across the existing set of exported products. By construction, lower value of the indices corresponds to higher degree of diversification. ${ }^{8}$ We follow IMF (2014) to construct the index using the 6-digit HS product level data on exports of each country and define groups at the 4-digit level.

Following, Cadot et al. (2011b), we estimate the following model for data spanning 1990 to 2015:

$$
D_{i, t}=\alpha+\beta_{1} Y_{i, t}+\beta_{2} Y_{i, t}^{2}+\beta_{3} P_{i, t}+\gamma \boldsymbol{X}_{i t}+\lambda_{t}+\boldsymbol{v}_{\boldsymbol{i}}+e_{i, t}
$$

\footnotetext{
${ }^{8}$ Both intensive and extensive margin of diversification are important from a policy perspective. A country which exports many products (high diversification along extensive margin), but 90 percent of the exports are concentrated in one product (low diversification along intensive margin), would still be subject to macrovolatility stemming from shock in that one sector. Hence diversifying along the intensive margin would still be important to reduce overall volatility.
}

(continued...) 
where $D_{i, t}$ is the average of the diversification index for country $i$ over a five-year period $t .^{9}$ In (1), $Y_{i, t}$ is the average $\log$ of real GDP per capita and $P_{i, t}$ is average $\log$ of population for country $i$, in period t. $\lambda_{t}$ are time specific effects captured by including time fixed effects through period specific dummies. $\boldsymbol{v}_{\boldsymbol{i}}$ is set of country specific variables that do not vary over time. $\boldsymbol{v}_{\boldsymbol{i}}$ includes latitude of a country and its 1970 GDP per capita to control for geography and convergence. ${ }^{10}$

Compared to Cadot et al. (2011b), there are two main enhancements - (i) the number of determinants in $\boldsymbol{X}_{\boldsymbol{i}, \boldsymbol{t}}$ is much bigger, and (ii) instead of OLS we use Bayesian Model Averaging (BMA).

The vector of potential determinants of diversification, $\boldsymbol{X}_{\boldsymbol{i}, \boldsymbol{t}}$, includes - resource rents and resource depletion, openness (goods and capital markets), market access, foreign direct investment (FDI), human capital, public expenditure and investment, exchange rate misalignment, terms of trade, financial market development, infrastructure, and quality of institutions (the complete list, including sources of key variables are shown in Table 1 in Appendix 1). Physical and human capital variables are lagged one period in (1).

With the large number of potential determinants of diversification there is significant uncertainty about the appropriate model. Hence we apply Bayesian Model Averaging (BMA) technique to determine which of the variables in vector $\boldsymbol{X}_{i t}$ are robust to model uncertainty and are important in explaining the variation in diversification. ${ }^{11}$ In the BMA exercise, we keep $Y_{i, t}, Y_{i, t}^{2}, P_{i, t}$ and $\boldsymbol{v}_{\boldsymbol{i}}$ fixed (always included) in the model, while allowing the algorithm to iterate over the potential determinants in $\boldsymbol{X}_{\boldsymbol{i}, \boldsymbol{t}}$. Thus, if there are $\boldsymbol{N}$ variables in $\boldsymbol{X}_{\boldsymbol{i}, \boldsymbol{t}}$, there are $2^{N}$ possible models to estimate with us being agnostic about the "true" model from this model space. The estimates of $\gamma$ are the weighted average of the parameter across different estimated models, with the weights being the posterior inclusion probability (PIP) of the variable in the "true" model. In interpreting the BMA results, following the literature we will consider variables with PIP above 0.5 to be robustly correlated with export diversification. ${ }^{12}$ The PIP also provides a way to rank the variables with regards to their importance in explaining variation in diversification across countries and over time. Higher PIP signals that a variable is more robustly associated with diversification. We also estimate (1) using OLS.

\footnotetext{
${ }^{9}$ The periods are 1990-1994, 1995-1999, 2000-2004, 2005-2009, 2010-2014 in the baseline sample. Cadot et al. (2011b) use annual data from 1990-2004, with 87 countries.

${ }^{10}$ We do not include (i) trade cost, measured by remoteness index, because of the presence of latitude, (ii) R\&D expenditure and trade liberalization measure because of lack of data on low-income countries.

${ }^{11}$ The BMA exercise is based on Magnus, Powell, and Prüfer (2010) using the bma command in stata.

${ }^{12}$ See Magnus, Powell, and Prüfer (2010) and Kass and Raftery (1995).
}

(continued...) 
In addition to estimating (1) for total Theil index, we also estimate it for between group Theil index (export diversification at the extensive margin) and within group Theil index (export diversification at the intensive margin). Lastly, we report the results for 4 different samples All countries (92), Emerging markets and developing economies (EMDE) (73), EMDE commodity exporters (EMDE-CE) (28) and EMDE diversified exporters (EMD-DE) (45). ${ }^{13}$

The Doing Business indicators from the World Bank which measure various aspects of the business climate can also signal potentially binding constraints on diversification. However, data for these indicators are only available from 2004, which significantly truncates our sample. Hence, we run two separate sets of regressions, one without the Doing Business indicators, and one with the Doing Business indicators.

\section{STYLIZEd FACTS}

This section presents facts on the diversification index and some of the important potential drivers. Due to better availability of data for these key drivers as well as the data on exports, we present the facts for the period 1975-2015 in contrast to the shorter period of 1990-2015 employed in the regressions. ${ }^{14}$ Table 1 shows the distributional statistics for the Theil index (across countries) by country groups for 1975 and 2015.

The first thing to note is the difference in the level of diversification across country groups AEs are more diversified than EMDEs, and EMDE-DEs are more diversified than EMDECEs. Over time, the median (as well as mean) diversification level for All countries has increased (Theil index decreased). However, trends differ between advanced economies (AEs) and EMDEs - AEs experienced a decrease whereas EMDEs experienced an increase in diversification. Among the EMDEs, the commodity and diversified exporters also behave differently - EMDE-CE have become less diversified whereas EMDE-DE have become more diversified. The dispersion in diversification, as measured by the IQR, increased between 1975 and 2015, except for AEs.

\begin{tabular}{|l|cc|ccc|cc|cc|c|}
\hline \multicolumn{10}{|c|}{ Table 1. Distribution Statistics of Diversification Index } \\
\hline \multirow{2}{*}{ Statistic } & \multicolumn{2}{c|}{ All countries } & \multicolumn{2}{c|}{ AE } & \multicolumn{1}{c|}{ EMDE } & \multicolumn{1}{c|}{ EMDE - CE } & EMDE - DE \\
\cline { 2 - 11 } & $\mathbf{1 9 7 5}$ & $\mathbf{2 0 1 5}$ & $\mathbf{1 9 7 5}$ & $\mathbf{2 0 1 5}$ & $\mathbf{1 9 7 5}$ & $\mathbf{2 0 1 5}$ & $\mathbf{1 9 7 5}$ & $\mathbf{2 0 1 5}$ & $\mathbf{1 9 7 5}$ & $\mathbf{2 0 1 5}$ \\
\hline Median & 3.74 & 3.49 & 1.96 & 2.20 & 4.05 & 3.86 & 4.35 & 4.53 & 3.73 & 3.16 \\
Mean & 3.75 & 3.56 & 2.12 & 2.38 & 4.12 & 3.85 & 4.54 & 4.53 & 3.84 & 3.43 \\
Inter-Quartile Range (IQR) & 1.68 & 2.04 & 1.15 & 0.78 & 1.51 & 1.92 & 1.61 & 1.66 & 1.37 & 1.77 \\
\hline
\end{tabular}

\footnotetext{
${ }^{13}$ Commodity exporters are countries where exports of fuel (Standard International Trade Classification [SITC] 3 ) and nonfuel primary products (SITCs 0, 1, 2, 4, and 68) exceed 50 percent of total exports.

${ }^{14} \mathrm{We}$ are restricted to using the shorter sample in the regression analysis as data for some of the covariates do not have data prior to that.
} 
Figure 1 shows the relationship between diversification and development, proxied by GDP per capita. For the All country sample diversification increases as income increases, but the eventual decrease in diversification with higher income is not observable as was found by IW. ${ }^{15}$ This becomes apparent when we split the sample into AEs and EMDEs. There is clear non-linearity observable among both AEs and EMDEs.

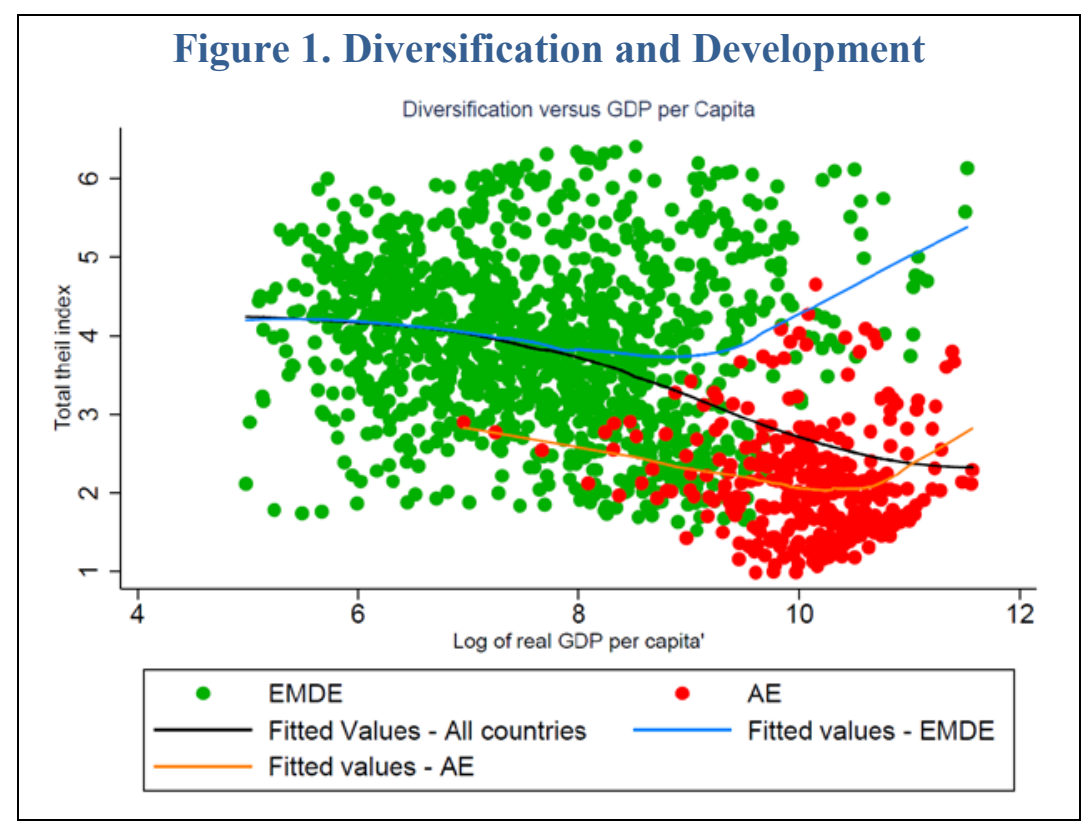

Figures 2 and 3 show the relationship (unconditional correlation) between the Theil index and select potential drivers of diversification, averaged over five-year periods. Human capital, size of a country (population), quality of institutions (International Country Risk Guide (ICRG) indicator of Quality of Government (QoG)), FDI, and level of financial sector development (Credit-to-GDP) are negatively correlated with the Theil index (and hence positively correlated with, level of diversification). However, FDI exhibits weak association with diversification, particularly for EMDEs. On the other hand, trade (\% of GDP) and public investment (\% of GDP) exhibits a weak positive relationship. Exchange rate undervaluation exhibits weak positive relationship for All countries, but a weak negative relationship for EMDEs. Exchange rate undervaluation is constructed following Rodrik (2008), with positive values indicating the currency is undervalued and negative values indicating the currency is overvalued. Thus, for All countries undervaluation is inversely correlated with diversification, for EMDEs it positively correlated with diversification.

We have a clearer intuition for the mechanism as well as the expected effect for some of these potential drivers of diversification, while for others the expected relationship is harder to ascertain. For instance, larger economies, proxied by population, will tend to be more diversified due to larger domestic markets and greater abundance of factors of productions;

\footnotetext{
15 This is due to the averaging over the 5-year periods.
} 
human capital is likely to encourage diversification through extensive margin (development of new products); better quality institutions are likely to help diversification through numerous channels, including better enforcement of contracts, limiting rent seeking and keeping barriers to entry low by imposing checks on corruption and excessive concentration of market power. A well-developed financial sector can help to increase access to credit which in turn could encourage new product creation through an increase in entrepreneurial activity and risk taking. It can also help to reduce distortions in credit allocation responsible for insufficient credit allocation to some sectors and overallocation to some others.

Trade and FDI can help diversification through investment in new products, but also deepen existing comparative advantage and thereby reduce diversification. ${ }^{16}$ Exchange rate overvaluation could undermine the tradable sectors' competitiveness, especially of manufacturing goods, which in turn could lead to lower diversification. This is the Dutch disease phenomenon highlighted among resource abundant countries.

Higher natural resource dependence is expected to reduce diversification by deepening the endowment driven comparative advantage. This what is captured in Figure 2, where resource dependence is measured by total natural resources rents (\% of GDP). Total natural resource rents are the sum of oil rents, natural gas rents, coal rents (hard and soft), mineral rents, and forest rents.

\footnotetext{
${ }^{16}$ Natural resources are often extracted by international companies, financing the activities through FDI, and hence, more FDI would be associated with higher resource sector activities and hence less diversification.
} 
Figure 2: Diversification and Potential Determinants
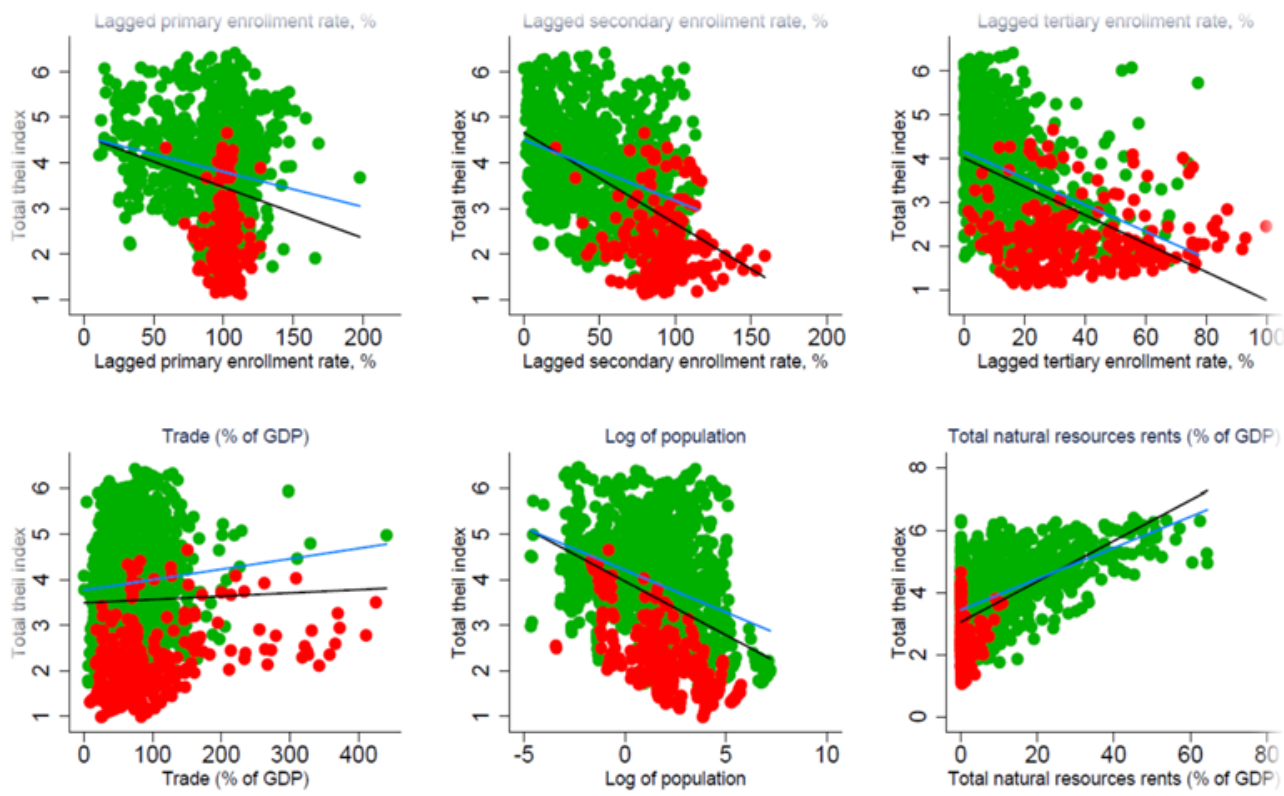

\begin{tabular}{|lll|}
\hline$\bullet \quad$ EMDE & & AE \\
& Fitted Values - All countries & \\
& Fitted values - EMDE
\end{tabular}

Figure 3. Diversification and Potential Determinants
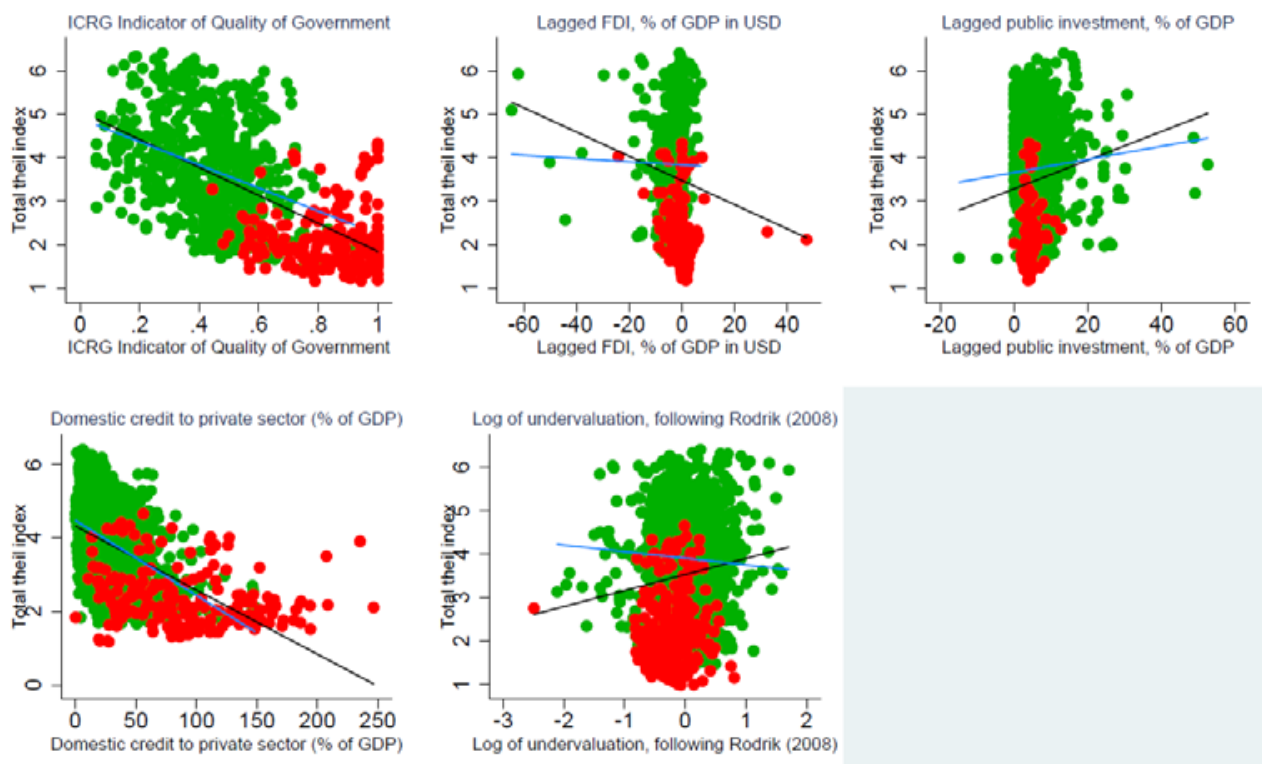

EMDE

Fitted Values - All countries

AE

Fitted values - EMDE 


\section{Drivers of Export Diversification: All Countries AND EMDEs}

Table 2 (Appendix 1) shows the results of estimating (1) for the three Theil indices using BMA and OLS for the samples of All countries and EMDEs. Note that some of the variables - GDP per capita, GDP per capita squared, population size, latitude and GDP per capita in 1970 - are always included in the model (as discussed above) and hence have PIPs have one by construction. ${ }^{17}$ The object of interest are other variables and their inclusion probabilities after controlling for the fact that GDP per capita, GDP per capita squared, population size, and fixed features such as latitude and GDP per capita in 1970 are already in controlled for in the model.

\section{Resource Endowment}

Natural resource rents are an important determinant of export diversification. ${ }^{18}$ Higher natural resource rent is associated with lower diversification, both at the intensive and extensive margins. In the BMA exercise the variable has a PIP of 1 across different specification and is highly significant in the OLS specifications. While the link between intensive margin of export diversification and natural resource rent is expected and is in part mechanical given that the extracted natural resources are likely to be exported, the second result suggests that countries with high natural resource rents also export fewer products. This suggests that the "resource curse" could be at play whereby abundance of natural resources undermines development of other tradeable sectors. It is worth noting, however, that the quantitative impact is larger on the intensive margin.

Faster depletion of natural resources does not appear to be positively or robustly associated with overall diversification. ${ }^{19}$ This is because higher rate of depletion appears to reduce diversification on the extensive margin but augments it on the intensive margin, with the two opposing effects cancelling each other out resulting in lack of statistical significance for the effect on the total Theil index. One may have conjectured that depletion of natural resources can spur policy action to diversify the economy. The empirical results however points to a possible role of resource curse which can undermine structural features of the economy (that are resistant to change) and make it difficult for countries to produce and export newer products, even when natural resources are running out. For example, in many oil exporting countries (such as in North Africa and the Middle East) the social contract is such that

\footnotetext{
${ }^{17}$ The PIPs of these variables are not informative about their importance in explaining variation in export diversification.

${ }^{18}$ Natural resources rents are the sum of oil rents, natural gas, rent, coal rents, mineral rents and forest rents

${ }^{19}$ Natural resource depletion is the sum of net forest depletion, energy depletion, and mineral depletion. Net forest depletion is unit resource rents times the excess of round wood harvest over natural growth. Energy depletion is the ratio of the value of the stock of energy resources to the remaining reserve lifetime. It covers coal, crude oil, and natural gas. Mineral depletion is the ratio of the value of the stock of mineral resources to the remaining reserve lifetime. It covers tin, gold, lead, zinc, iron, copper, and nickel.
} 
citizens expect and rely on transfers from the state, which are in turn generated through oil exports. This in turn can lead to weak incentives to participate in labor market at competitive wages and undermine overall competitiveness of non-resource sectors. Changing this social contract can be challenging even if its unsustainable in the medium to long term given the finite resource horizon.

\section{Human Capital}

Primary education is positively associated with overall level of diversification, and it impacts both the extensive and the intensive margin of diversification. While, secondary and tertiary education do not exhibit significant association with diversification for the two samples in Table 2 in the BMA exercise, we will see later that these variables do become important for different sub samples.

\section{Cross-Border Flows: Trade and Investment}

Countries that trade more have greater export diversification, mainly through the extensive margin. In the BMA exercise where the dependent variable is the extensive margin of diversification, trade as a share of GDP has a posterior inclusion probability of 1 or very close to 1, suggesting that greater openness improves diversification by expanding the set of products that are exported. The high inclusion probability suggests it is one of the important variables in understanding variation in export diversification. ${ }^{20}$ Preferential trade agreements do not have a statistically significant impact in any sample.

Higher foreign direct investment (FDI) appears to be associated with higher degree of specialization or lower levels of export diversification, mainly at the extensive margin, albeit the correlation is weaker in the EMDE sample with a PIP of less than 0.5. This is likely because FDI tends to flow into sectors where countries have an established comparative advantage and possibly strengthens these sectors compared to others. This could particularly be the case for the mining sector in commodity exporting countries with narrow export base during the sample period.

Capital account openness, measured by the Shin and Ito capital account openness index, also exhibits robust negative association with Theil index, i.e. less restricted capital flows are associated with higher diversification. The effect operates through the intensive margin.

\section{International Relative Prices}

\footnotetext{
${ }^{20}$ We have also proxied (lack of) openness by using average tariff rates in place of the trade-to-GDP ratio. While we lose a considerable number of observation when we do this, the qualitative direction of the results remains unchanged - greater openness (lower tariff rates) are associated with greater diversification. However, tariffs are not as robustly associated with diversification as trade-to-GDP in the All country sample. The association is stronger in the EMDE sample.
} 
The change in terms of trade and the measure of exchange rate undervaluation do not appear to be significantly associated with diversification. This is perhaps due to the fact that the channel through which it can affect diversification - trade flow - are already accounted for in the specification and is a more important determinant of diversification.

Aghion et al. (2009), focusing on productivity growth, find evidence that exchange rate volatility can have a significant negative impact on long run productivity growth when financial markets are underdeveloped. ${ }^{21}$ Excess volatility of the exchange rate can produce excess volatility in firms profits and hence lower the economy wide investment rate, which can affect long-run growth though insufficient innovation. This could have a disproportionately large effect on investment industries which require significant upfront investment and thereby stall diversification into more sophisticated products. We augment our baseline specification, with exchange rate volatility measured by the 5-year standard deviation of the real exchange rate, and terms of trade volatility and their interaction with credit-to-GDP which proxies for level of financial development. We find that these do not have statistically significant impact on diversification. The lack of a significant effect is robust to differentiating between extensive and intensive margins of diversification. We do not report these results here for the sake of brevity.

\section{Quality of institutions}

Higher quality of governance (ICRG index of Quality of Institutions) is associated with the higher degree of export diversification, largely at the extensive margin. The quality of governance measure is the average of the indices for Corruption, Law and Order and Quality of Bureaucracy from the International Country Risk Guide database normalized to one. ${ }^{22}$ Poorer governance is thus associated with export being concentrated in fewer products. Democracy, on the other hand, does not appear to be robustly associated with diversification.

\section{Infrastructure}

Fixed telephone subscription which proxies for connectivity and infrastructure development within an economy is strongly associated with extensive margin of diversification. Similarly, mobile phone subscriptions are associated with intensive margin diversification. However, these associations do not hold among the EMDEs. Though we do not report the results here, other proxies for infrastructure such as road density and ICT development (access to computer and access to internet) do not show a robust relationship with diversification. ${ }^{23}$

\footnotetext{
22 Results were unchanged when we used the Worldwide Governance Indicators.

${ }^{23}$ Data availability for road density is sparse.
} 
Interestingly, public investment as a share of GDP has a negative correlation with diversification, via the extensive margin. ${ }^{24}$

\section{Financial Sector Development}

Though credit to the private sector, measured by the credit-to-GDP ratio, is not associated with diversification for the sample of All countries, it is associated with increase in diversification among the EMDEs, but only along the intensive margin. Thus, a more developed financial sector helps to diversify economies.

\section{DRIVERS OF EXPORT DIVERSIFICATION: EMDE COMMODITY EXPORTERS VERSUS DIVERSIFIED EXPORTERS}

Table 3 (Appendix 1) presents the results for the baseline specification (of Table 2) for commodity and diversified exporters within the group of EMDEs.

\section{Resource Endowment}

Natural resource rent as a share of GDP appears to be highly significant and robustly associated with the degree of diversification among the EMDE-CE, both at the intensive and extensive margins though the PIP for the former is marginally lower than 0.5. Higher resource rent not only depresses the intensive margin of diversification in EMDE-CE, which is expected, it also reduces the number of products a country produces. However, among the EMDE-DEs, the picture is different. While natural resource rents depress total as well as intensive margin diversification, they help to facilitate diversification at the extensive margin. The extensive margin channel also has sufficiently high PIP whereas the intensive margin channel has a PIP less than 0.5. The stark difference in the effect of resource rents on extensive margin diversification across the two sets of countries could be due to (a) a substantially larger size of sub-soil wealth among commodity exporters compared to diversified exporters and (b) better management of resource revenues by the state among diversified exporters in terms of financing productive spending in non-resource sectors.

The depletion of natural resource does not appear to be robustly associated with higher diversification for commodity exporters. While the OLS shows positive association for total diversification and the intensive margin, these results are not robust in the BMA analysis. Moreover, the lack of significance of depletion rate for the extensive margin for both the

\footnotetext{
${ }^{24}$ Earlier versions of the paper also included public consumption, which was negatively associated with the theil index. However, to separate public expenditure on human capital development, when we stripped out expenditure on education, the correlation was statistically insignificant. This could also be due to a significant loss of observations as data on public expenditure on education is limited.
} 
OLS and BMA is quite telling and supports the notion that commodity exporters struggle to produce and export newer products even when natural resources are depleting fast.

Diversified exporters experience a decrease in diversification - total as well as at the extensive margin - when depletion rates rise, which could be because they choose to not export the natural resources (and use it only for local consumption) when they are running out or likely to run out. ${ }^{25}$

\section{Human Capital}

Table 3 also reveals that primary education's role in driving diversification among EMDEs, seen in Table 2, is mainly due to diversified exporters via the intensive margin. Furthermore, higher secondary enrollment aids diversification at the extensive margin in EMDE-CEs. Higher tertiary enrolment rates help to increase intensive margin diversification among the EMDE-DEs. Thus, diversified exporters and commodity exporters need to focus on different dimensions of human capital accumulation via schooling to diversify their export base.

\section{Cross-Border Flows: Trade and Investment}

Greater trade openness proxied by total trade as a share of GDP has opposing effects on the intensive and extensive margins of diversification for commodity exporters. This result is distinctly different from what we got in the sample for EMDEs (as well as for All countries). On the one hand, greater trade openness leads to greater number of products on the other hand it leads to greater concentration of exports in a few products among commodity exporters. The two effects offset each other causing the effect on total diversification to not be significantly different from zero. Preferential trade agreements do not have a statistically significant impact in any sample.

Foreign direct investment does not play an important role among commodity as well as diversified exporters.

\section{International Relative Prices}

Splitting the EMDE sample into commodity and diversified exporters does not affect the lack of association between diversification and the change in terms of trade and the measure of exchange rate undervaluation observed for the All countries and EMDEs.

\section{Infrastructure}

There appears to be little evidence that infrastructure, proxied by fixed phone and mobile phone subscriptions, is associated with more diversification among commodity exporters. We

\footnotetext{
${ }^{25}$ Bangladesh, a diversified exporter, for example, has decided not to export natural gas and only use it for local consumption given the limited horizon of its gas reserves.
} 
find that higher public investment is associated with lower diversification at the extensive margin. This could be because higher rents from natural resource extraction allows countries to increase their public investment. These measures together with public investment rate are also not robustly associated with diversification for diversified exporters.

\section{Quality of Institutions}

When we divide the EMDEs into commodity and diversified exporters we find that higher quality of institutions (higher ICRG score) are diversification enhancing, but the effect is statistically insignificant. While the OLS appears significant at extensive margin for EMDECEs, the association is not robust in the BMA analysis. Having said that, the association between Democracy and total diversification for EMDE-CEs is positive and has a PIP that is almost 0.5 . This effect is largely driven by the intensive margin.

\section{Financial Sector Development}

As observed in the full sample of EMDEs credit to the private sector, helps to increase diversification in both commodity exporters and diversified exporters. The effect is statistically significant only for the intensive margin. For the commodity exporters, this could be symptomatic of the negative effect that a large stock of sub-soil wealth can have on the allocation of credit between the resource and non-resource tradable sectors.

\section{DOING BUSINESS INDICATORS AND DIVERSIFICATION}

We augment our baseline set of macro variables with World Bank's enterprise survey based Doing Business (DB) indicators, which measure various aspects of the business climate and can signal potentially binding constraints on diversification. However, data for these indicators are only available from 2004, which significantly truncates our sample. Table 4 (Appendix 1) shows the results of estimating equation 1 after including the Doing Business indicators. $^{26}$

Among the Doing Business indicators (DBI) costs of trading across border appears to be robustly correlated with diversification - lower costs of trading across borders (higher DTF values) are associated with greater diversification. Furthermore, the cost of trading across borders affects the intensive margin of diversification. None of the other DB indicators exhibit robust association with diversification. Among the core set of macro variables, compared to the baseline specification, we observe that enrollment rates lose statistical significance. This is mainly due to loss in observations. Trade-to-GDP also loses its statistical power, except for the extensive margin for the All countries sample. This may be due to the inclusion of the cost of trading across border, which also captures trade openness.

\footnotetext{
${ }^{26}$ Among all available Doing Business indicators, we excluded getting electricity because their inclusion significantly reduces the sample due to poor data coverage.
} 


\section{POLICY IMPlications}

The analysis in this paper has important implications for policy makers who are seeking to diversify their economies. It highlights some of the key factors that predisposes them toward lower export diversification - size of the economy, geography and natural resource abundance. Moreover, even among the commodity exporters, countries with higher natural resource rents are likely to export fewer products after controlling for other factors, including quality of institutions. It also highlights areas where policy actions to improve export diversification are most likely to bear fruit, based on the statistical robustness of their association with diversification.

- Human capital accumulation. Education is a crucial factor for export diversification. Primary education is robustly associated with export diversification, with the dominant effect being on the set of products a country exports. Improvement in human capital can increase the number of products a country can potentially produce, and export competitively, and hence directly impacts its comparative advantage vis-àvis trade partner, which in turn affects export diversification. For commodity exporters secondary education is the more important dimension to improve export diversification. Again, it is robustly associated with the number of products a country exports. It is only out-ranked by openness among the policy variables tested in our model. While we do not explore the importance of quality of education, the literature has established the importance of quality of education for growth and labor market outcomes in addition to the importance of quantity of education. Thus, policies aimed at improving education outcomes must focus on quantity as well as quality of education.

- $\quad$ Trade openness. Countries that trade more tend to have greater export diversification, both at the intensive and extensive margin. This effect is borne out even among the set of Doing Business indicators, where lower trade costs is the only variable that is important in explaining the variation in diversification. For the bigger - all country and EMDE - samples, the positive effect of openness operates mainly through the set of products exported. For commodity exporters among the EMDEs, openness can help to diversify exports along the extensive margin, and it is the most robustly associated determinant of diversification. However, this effect is countered by the greater specialization induced by trade at the intensive margin.

- Quality of institution. Higher quality of institution as measured by the quality of governance is associated with less concentrated export base, and higher overall level of diversification.

- Infrastructure. We find evidence that higher level of infrastructure provision, proxied by higher fixed telephone penetration, is important for the extensive margin of 
diversification. Higher mobile phone penetration is associated with diversification at the intensive margin.

- Capital account openness. Greater openness to capital flows also helps diversification by positively affecting the intensive margin of diversification.

- $\quad$ Financial sector development. Lastly, more developed financial sector can help to diversify EMDEs at the intensive margin, and this effect survives even among commodity exporters and diversified exporters. Thus, policies to improve both financial access and the allocation of credit across sectors (and across firms within sectors) would be beneficial, especially among commodity exporters given the significant Dutch disease effect.

Thus, resource abundant economies need to focus on overcoming the export product space limiting effect of resources wealth by having more open trade regimes, improving education outcomes for secondary and higher education, and developing their financial sector to increase access to and improving allocation of credit.

\section{CONCLusion}

This paper attempts to address the question of how to diversify. We identify key factors, from a pool of large number of potential determinants, that explain the variation in export diversification across countries and over time using Bayesian Model Averaging, which addresses the issue of model uncertainty. Our methodology allows us to rank variables in terms of their importance in explaining the variation in export diversification in the data and hence helps to prioritize areas for policy actions.

Expectedly, we find that natural resource abundance and smaller size (in terms of population) predispose countries towards being less diversified. However, more importantly, higher natural resource rent is associated with lower export diversification not only at the intensive margin but also at the extensive margin. The negative effect on the extensive margin is akin to the Dutch disease effect of resources on growth discussed in the context of the literature on the resource curse. Our analysis suggests that to diversify, policy makers should prioritize human capital accumulation and reduce barriers to trade. Other policy areas include (in order of importance) improving quality of institutions, quality of infrastructure and deepening financial markets. For commodity exporters: (i) secondary education is the most important driver of diversification; (ii) greater trade is associated with greater number of products exported; and (iii) improving access as well as allocation of credit

One must be careful in interpreting the findings as evidence of causality. Though we significantly expand the set of regressors, controlling for important time-invariant features of economies (initial GDP and geography), we follow the literature in adopting the specification. This implicitly views the regressors as the causal factors, but as is the case with most of the literature, our methodology does not address the issue of identification 
completely. While physical capital and human accumulation variables are included as lags, and trade openness is also proxied using tariff rates and Doing Business indicator on costs of trading across border, addressing causality adequately will require instruments for the full set of regressors. This is quite challenging given the large set of regressors considered.

There remain interesting avenues for further research. Our focus is on the level of diversification and not on the nature of diversification. For instance, we do not differentiate between diversification within agriculture from diversification from agriculture into manufacturing as long as the theil index changes by the same amount in both cases. But, this qualitative difference between various paths of diversification may be important from a growth stand-point, and therefore should be examined.

The role of industrial policies in enhancing diversification has garnered a lot of attention recently (see Aghion et al. (2011)), in part due to the rapid economic transformation of China. Cherif at al. (2016) and Cherif and Hasanov (2019) delve into this issue and make a case for the role of the state in the process of development. We do not address this issue mainly due to a lack of comparable data on different policy instruments across countries and over time. Leveraging firm level data to understand differences in firm level characteristics across certain groups of countries within the same industries, such as commodity versus diversified exporters is also an interesting area for future research. This could shed light on the key constraints that must be addressed to ensure desirable firm level dynamics and efficient allocation of resources (see Hsieh and Klenow (2014, 2009)). Finally, our paper did not explore labor and product market reforms, as data availability is poor especially among LICs, and these reforms could also be important for diversification. 


\section{References}

Aghion, P., Philippe B., Romain R., \& Kenneth R., 2009, "Exchange Rate Volatility and Productivity Growth: The Role of Financial Development," Journal of Monetary Economics, Vol. 56, No. 4, pp: 494-513.

Aghion, P., Julian, B., \& Elie, C., 2011, “Rethinking Industrial Policy,” Bruegel Policy Brief.

Alexeev, M. and Conrad R., 2009, “The Elusive Curse of Oil,” Review of Economics and Statistics, Vol. 91, No. 3, pp. 586-598.

Auty, R., 1993, "Sustaining Development in mineral Economies: The Resource Curse Thesis," (Oxford: Oxford University Press).

Brunnschweiler, C. N. and E. H. Bulte, 2008, "The Resource Curse Revisited and Revised: A Tale of Paradoxes and Red Herrings," Journal of Environmental Economics and Management, Vol. 55, No. 3, pp. 248-64.

Bulte, E. H. and Richard D., 2008, "Resources for Sale: Corruption, Democracy and the Natural Resource Curse,” B.E. Journal of Economic Analysis and Policy, 8(1).

Cadot, O., C. Carrere \& V. Strauss-Kahn, 2011a, "Export Diversification: What's Behind the Hump?," Review of Economics and Statistics, Vol. 93, Issue 2.

Cadot, Olivier, Carrere, Celine and Strauss-Kahn (2011b), "Trade Diversification: Drivers and Impacts," chapter in ILO-EU co-publication "Trade and Employment: From Myths to Facts” (M. Jansen, R. Peters and J. M. Salazar Xirinachs (Eds.)).

Callen, T., R. Cherif, F Hasanov, A. Hegazy \& P. Khandelwal, 2014, "Economic diversification in the GCC: Past, present, and future," IMF Staff Discussion Notes 14/12, (Washington, DC: International Monetary Fund).

Cherif, R., F Hasanov \& M Zhu (eds) (2016), “Breaking the oil spell: The Gulf Falcons' path to diversification," (Washington, DC: International Monetary Fund).

Cherif, R., and F. Hasanov, 2019, "The Return of the Policy That Shall Not Be Named: Principles of Industrial Policy,” IMF Working Paper No. 19/74, (Washington DC: International Monetary Fund).

Collier, P. and Anke H., 2009, "Testing the Neocon Agenda: Democracy in Resource-Rich Societies," European Economic Review, Vol. 5, No. 3, pp. 293-308.

Caselli, F. and Tom C., 2009, "Leader Behaviour and the Natural Resource Curse," Oxford Economic Papers,Vol. 61, No. 4, pp. 628-50. 
Diao, X., Margaret S. McMillan, \& Dani R., 2017, “The Recent Growth Boom in Developing Economies: A Structural Change Perspective,” NBER Working Paper 23132.

Haddad, M., J.J. Lim, and C. Saborowski, 2013, “Trade Openness Reduces Growth Volatility When Countries are Well Diversified," Canadian Journal of Economics, Vol. 46, pp. 765790 .

Hausmann, R. and Dani R., 2003, “Economic Development as Self-Discovery,” Journal of Development Economics Vol. 72, Issue 2, pp. 603-633.

Herrendorf B., Richard R., \& Ákos V., 2014, “Growth and Structural Transformation,” Handbook of Economic Growth, Volume 2B.

Hsieh, Chang-Tai, \& Peter J. Klenow, 2009, "Misallocation and Manufacturing TFP in China and India," The Quarterly Journal of Economics, Volume 124, Issue 4, pp. 14031448.

Chang-Tai and Peter J. K., 2014, "The Life Cycle of Plants in India and Mexico," The Quarterly Journal of Economics, Volume 129, Issue 3, August 2014, pp. 1035-1084.

IMF (2014), "Sustaining Long-Run Growth and Macroeconomic Stability in Low-Income Countries - The Role of Structural Transformation and Diversification" (Washington).

IMF (2017), "Regional Economic Outlook, Sub-Saharan Africa” (Washington).

Imbs J., and Romain W., 2003, "Stages of Diversification," American Economic Review, Vol. 93, No. 1, pp. 63-86.

Kaldor, M., T.L. Karl \& Y. Said., 2007, “Oil Wars,” Pluto Press, edited by M. Kaldor.

Kass, Robert E., \& Adrian E. Raftery, 1995, "Bayes Factors,” Journal of the American Statistical Association, Vol. 90, No. 430, pp. 773-795.

Klinger, B., and D. Lederman, 2006, "Diversification, Innovation and Imitation Inside the Global Technology Frontier,” World Bank Policy Research Working Paper \#3872 (Washington DC: World Bank).

Koren, M. and S. Tenreyro, 2007, "Volatility and Development", Quarterly Journal of Economics, Vol. 122, pp. 243-87.

Magnus, J. R., \& Owen P., 2010, “A Comparison of Two Model Averaging Techniques with an Application to Growth Empirics," Journal of Econometrics, Vol. 154, Issue 2, pp. 139153. 
Rodrik, D., 2016, "Premature Deindustrialization," Journal of Economic Growth, Springer, Vol. 21, No. 1, pp. 1-33.

Rockey, J., \& Jonathan T., 2016, "Growth Econometrics for Agnostics and True Believers," European Economic Review, Vol. 81, pp. 86-102.

Sachs, J., \& Andrew W., 1995, "Natural Resource Abundance and economic Growth," in G. Meier and J Rauch, eds., Leading Issues in Economic Development (New York: Oxford University Press).

Samaniego, R., \& Juliana S., 2016, "Productivity Growth and Structural

Transformation," Review of Economic Dynamics, Vol. 21, pp 266-285.

Sala-i-Martin, X., \& Arvind S., 2003, "Addressing the Natural Resource Curse: An Illustration from Nigeria,” IMF Working Paper WP/03/139, (Washington DC:

International Monetary Fund). 


\section{Appendix I}

\begin{tabular}{|c|c|c|}
\hline \multicolumn{3}{|c|}{ Table 1. Summary of Variables } \\
\hline Variables & Definition & Data Source \\
\hline \multicolumn{3}{|l|}{ Dependent Variables } \\
\hline Total Theil Index & Measure of total diversification & Computed based on UN Contrade data \\
\hline Between Theil Index & Extensive margin of diversification & Computed based on UN Contrade data \\
\hline Within Theil Index & Intensive margin of diversification & Computed based on UN Contrade data \\
\hline \multicolumn{3}{|l|}{ Independent Variables } \\
\hline Log of GDP per capita & Expenditure-side real GDP chained PPPs in million 2011 US\$ per capita, in natural logs & PWT 9.0 \\
\hline Log of GDP per capita square & Square of Log GDP per capita & Computed \\
\hline Log of Population & Population, in natural logs & WEO \\
\hline Absolute latitude & Absoluted latitude & Sala-I-Martin et al. (2004) \\
\hline Real GDP per capita (PPP) in 1970 & Real GDP per capita (PPP) in 1970 & Computed using data from PWT 9.0 \\
\hline Inflation & Inflation rate (percent change in CPI) & WEO \\
\hline Natural Resource Rent & Total natural resources rents (\% of GDP) & WDI \\
\hline Natural Resource Depletion (\% of GNI) & Adjusted savings: natural resources depletion (\% of GNI) & WDI \\
\hline Trade to GDP & Trade (\% of GDP) & WDI \\
\hline Capital Account Openness & Capital account openness index & Chin \& Ito database \\
\hline Preferential Trade Agreement & Market access measure: weighted sum of preferential trade agreements (PTAs) & $\begin{array}{l}\text { Computed: GDP data from WDI; PTA dat } \\
\text { Jeffrey Bergstrand's EIA database }\end{array}$ \\
\hline Foreign Direct Investment (lagged) & Lagged: Foreign direct investment, (BPM6), percent of GDP in U.S. dollars & WEO \\
\hline Primary School Enrollment (Lagged) & Lagged: Gross enrollment ratio, primary, both sexes (\%) & WDI \\
\hline Secondary School Enrollment (Lagged) & Lagged: Gross enrollment ratio, secondary, both sexes (\%) & WDI \\
\hline Tertiary Education (Lagged) & Lagged: Gross enrollment ratio, tertiary, both sexes (\%) & WDI \\
\hline Public Investment (lagged) & Lagged: Public Investment (\% of GDP) & WEO \\
\hline Exchange Rate Undervaluation Index & Exchange rate undervaluation index (following Rodrick (2008)) & Computed using data from WEO, WDI an \\
\hline Terms of Trade & Terms of trade, total, US Dollars & WEO \\
\hline Credit to Private Sector & Domestic credit to private sector (\% of GDP) & WDI \\
\hline Fixed Phone Subscription (per 100 people) & Fixed telephone subscriptions (per 100 people) & WDI \\
\hline \multirow[t]{2}{*}{ Mobile Phone Subscription (per 100 people) } & Mobile cellular subscriptions (per 100 people) & WDI \\
\hline & ICRG: Quality of Government; The mean value of the ICRG variables "Corruption", "Law and & \\
\hline \multirow[t]{2}{*}{ Quality of Institution (ICRG) } & $\begin{array}{l}\text { Order" and "Bureaucracy Quality", scaled 0-1. Higher values indicate higher quality of } \\
\text { government. }\end{array}$ & QoG institute \\
\hline & Combined policy score: The polity score is computed by subtracting the $p_{-}$autoc score from the & \\
\hline Democracy (Polity 2) & $\begin{array}{l}\text { P_democ score; the resulting unified polity scale ranges from }+10 \text { (strongly democratic) to }-10 \\
\text { (strongly autocratic) }\end{array}$ & QoG institute \\
\hline Starting a Business - DTF & Doing business component: Starting a Business DTF & World Bank - Doing Business \\
\hline Dealing with Construction Permits - DTF & Doing business component: Dealing with Construction Permits DTF & World Bank - Doing Business \\
\hline Registering Property - DTF & Doing business component: Registering Property DTF & World Bank - Doing Business \\
\hline Getting Credit - DTF & Doing business component: Getting Credit DTF & World Bank - Doing Business \\
\hline Protecting Minority Investors - DTF & Doing business component: Protecting Minority Investors DTF & World Bank - Doing Business \\
\hline Paying Taxes - DTF & Doing business component: Paying Taxes DTF & World Bank - Doing Business \\
\hline Trading across Borders - DTF & Doing business component: Trading across Borders DTF & World Bank - Doing Business \\
\hline Enforcing Contracts - DTF & Doing business component: Enforcing Contracts DTF & World Bank - Doing Business \\
\hline Resolving Insolvency - DTF & Doing business component: Resolving Insolvency DTF & World Bank - Doing Business \\
\hline
\end{tabular}


Table 2. Baseline Specification, All Countries and EMDEs

\begin{tabular}{|c|c|c|c|c|c|c|c|c|c|c|c|c|}
\hline & \multicolumn{6}{|c|}{ All Countries: Full Sample } & \multicolumn{6}{|c|}{ EMDE: Full Sample } \\
\hline & OLS & BMA & OLS & BMA & OLS & BMA & OLS & BMA & OLS & BMA & OLS & BMA \\
\hline \multirow{3}{*}{$\begin{array}{l}\text { Variables } \\
\text { Log of Real GDP per Capita }\end{array}$} & \multicolumn{2}{|c|}{ Total Theil Index } & \multicolumn{2}{|c|}{ Between Theil Index } & \multicolumn{2}{|c|}{$x$ Within Theil Index } & \multicolumn{2}{|c|}{ Total Theil Index } & \multicolumn{2}{|c|}{ Between Theil Index } & \multicolumn{2}{|c|}{ Within Theil Index } \\
\hline & -0.411 & -0.059 & -0.293 & -0.488 & -0.118 & -0.311 & 0.487 & 0.557 & -0.522 & -0.687 & 1.009 & 1.035 \\
\hline & 0.613 & 1.00 & 0.365 & 1.00 & 0.687 & 1.00 & 0.714 & 1.00 & 0.440 & 1.00 & 0.807 & 1.00 \\
\hline \multirow[t]{2}{*}{ Log of Real GDP per Capita (squared) } & 0.036 & 0.005 & 0.030 & 0.042 & 0.005 & 0.009 & -0.016 & -0.030 & 0.044 & 0.053 & -0.060 & -0.071 \\
\hline & 0.038 & 1.00 & 0.023 & 1.00 & 0.043 & 1.00 & 0.044 & 1.00 & 0.027 & 1.00 & 0.050 & 1.00 \\
\hline \multirow[t]{2}{*}{ Log of Poulation } & $-0.251 * * *$ & -0.261 & $-0.076 * * *$ & -0.078 & $-0.175^{* * *}$ & -0.174 & $-0.238 * * *$ & -0.224 & $-0.081 * * *$ & -0.070 & $-0.157^{* * *}$ & -0.185 \\
\hline & 0.030 & 1.00 & 0.018 & 1.00 & 0.033 & 1.00 & 0.035 & 1.00 & 0.021 & 1.00 & 0.039 & 1.00 \\
\hline \multirow[t]{2}{*}{ Absolute Latitude } & $-0.009 * *$ & -0.010 & $-0.004^{*}$ & -0.004 & -0.005 & -0.005 & $-0.010^{*}$ & -0.011 & $-0.005^{*}$ & -0.006 & -0.005 & -0.004 \\
\hline & 0.003 & 1.00 & 0.002 & 1.00 & 0.004 & 1.00 & 0.004 & 1.00 & 0.002 & 1.00 & 0.004 & 1.00 \\
\hline \multirow[t]{2}{*}{ Real GDP per capita (PPP) in 1970} & 0.000 & 0.000 & $0.000^{*}$ & 0.000 & $-0.000^{*}$ & 0.000 & 0.000 & 0.000 & $0.000^{*}$ & 0.000 & 0.000 & 0.000 \\
\hline & 0.000 & 1.00 & 0.000 & 1.00 & 0.000 & 1.00 & 0.000 & 1.00 & 0.000 & 1.00 & 0.000 & 1.00 \\
\hline \multirow[t]{2}{*}{ Natural Resource Rent } & $0.059 * * *$ & 0.057 & $0.012^{* *}$ & 0.009 & $0.047^{* * *}$ & 0.042 & $0.063^{* * *}$ & 0.054 & 0.009 & 0.002 & $0.053^{* * *}$ & 0.055 \\
\hline & 0.008 & 1.00 & 0.005 & 0.70 & 0.009 & 1.00 & 0.009 & 1.00 & 0.005 & 0.24 & 0.010 & 1.00 \\
\hline \multirow[t]{2}{*}{ Natural Resource Depletion (\% of GNI) } & -0.012 & -0.001 & $0.020 * * *$ & 0.023 & $-0.032 * *$ & -0.021 & -0.020 & -0.003 & $0.027^{* * *}$ & 0.034 & $-0.048^{* * *}$ & -0.041 \\
\hline & 0.010 & 0.08 & 0.006 & 0.96 & 0.011 & 0.69 & 0.011 & 0.17 & 0.007 & 1.00 & 0.012 & 0.97 \\
\hline \multirow[t]{2}{*}{ Primary School Enrollment Rate (lagged) } & $-0.009 * * *$ & -0.009 & $-0.003^{* *}$ & -0.004 & $-0.005^{*}$ & -0.003 & $-0.009^{* * *}$ & -0.010 & $-0.003^{*}$ & -0.004 & $-0.006^{*}$ & -0.002 \\
\hline & 0.002 & 1.00 & 0.001 & 0.99 & 0.002 & 0.51 & 0.002 & 1.00 & 0.001 & 0.95 & 0.002 & 0.39 \\
\hline \multirow[t]{2}{*}{ Secondary School Enrollment Rate (lagged) } & -0.003 & -0.001 & -0.003 & 0.000 & -0.001 & 0.000 & 0.000 & 0.000 & $-0.004 *$ & -0.001 & 0.004 & 0.000 \\
\hline & 0.003 & 0.22 & 0.002 & 0.12 & 0.003 & 0.12 & 0.003 & 0.10 & 0.002 & 0.25 & 0.004 & 0.07 \\
\hline Tertiary School Enrollment Rate (lagged) & -0.001 & -0.001 & $0.005^{*}$ & 0.001 & -0.005 & -0.001 & -0.002 & -0.001 & $0.008^{* *}$ & 0.001 & -0.010 & -0.005 \\
\hline & 0.003 & 0.14 & 0.002 & 0.23 & 0.004 & 0.20 & 0.005 & 0.14 & 0.003 & 0.19 & 0.006 & 0.48 \\
\hline Trade to GDP & $-0.003^{*}$ & -0.004 & $-0.003^{* * *}$ & -0.003 & 0.000 & 0.000 & -0.003 & -0.001 & $-0.005^{* * *}$ & -0.004 & 0.002 & 0.000 \\
\hline & 0.001 & 0.91 & 0.001 & 1.00 & 0.001 & 0.07 & 0.002 & 0.27 & 0.001 & 1.00 & 0.002 & 0.08 \\
\hline Preferential Trade Agreement & -0.160 & -0.007 & -0.023 & -0.001 & -0.137 & -0.005 & -0.212 & -0.026 & -0.287 & -0.045 & 0.075 & -0.005 \\
\hline & 0.202 & 0.06 & 0.120 & 0.05 & 0.226 & 0.06 & 0.282 & 0.09 & 0.174 & 0.17 & 0.319 & 0.06 \\
\hline Capital Account Openness & $-0.490 * * *$ & -0.572 & -0.045 & -0.005 & $-0.445 * *$ & -0.490 & $-0.485^{* * *}$ & -0.562 & 0.001 & -0.003 & $-0.487 * *$ & -0.423 \\
\hline & 0.127 & 1.00 & 0.075 & 0.08 & 0.142 & 0.98 & 0.144 & 0.99 & 0.089 & 0.07 & 0.162 & 0.87 \\
\hline Foreign Direct Investment (\% of GDP) (lagged) & $0.029 *$ & 0.010 & $0.024 * *$ & 0.017 & 0.005 & 0.001 & 0.029 & 0.019 & $0.030^{*}$ & 0.011 & 0.000 & 0.000 \\
\hline & 0.014 & 0.33 & 0.009 & 0.72 & 0.016 & 0.06 & 0.020 & 0.44 & 0.012 & 0.42 & 0.022 & 0.06 \\
\hline Exchange Rate Undervaluation Index & -0.131 & -0.002 & 0.010 & 0.001 & -0.141 & -0.004 & -0.165 & -0.005 & 0.023 & 0.002 & -0.188 & -0.004 \\
\hline & 0.116 & 0.05 & 0.069 & 0.05 & 0.130 & 0.06 & 0.130 & 0.06 & 0.080 & 0.06 & 0.147 & 0.06 \\
\hline Terms of Trade (log difference) & 0.401 & 0.033 & -0.674 & -0.145 & 1.076 & 0.179 & 0.311 & 0.028 & -0.640 & -0.095 & 0.952 & 0.127 \\
\hline & 0.671 & 0.06 & 0.400 & 0.20 & 0.752 & 0.15 & 0.713 & 0.06 & 0.439 & 0.15 & 0.806 & 0.12 \\
\hline Public Investment (\% of GDP) (lagged) & 0.015 & 0.004 & $0.013^{*}$ & 0.007 & 0.002 & 0.000 & $0.018^{*}$ & 0.011 & $0.012^{*}$ & 0.008 & 0.006 & 0.001 \\
\hline & 0.008 & 0.26 & 0.005 & 0.54 & 0.009 & 0.05 & 0.009 & 0.50 & 0.006 & 0.57 & 0.010 & 0.08 \\
\hline Fixed Phone Subscription (per 100 people) & -0.007 & -0.001 & $-0.010^{* *}$ & -0.010 & 0.003 & 0.000 & -0.017 & -0.003 & -0.008 & -0.001 & -0.009 & -0.001 \\
\hline & 0.005 & 0.16 & 0.003 & 0.97 & 0.006 & 0.05 & 0.009 & 0.22 & 0.005 & 0.11 & 0.010 & 0.09 \\
\hline Mobile Phone Subscription (per 100 people) & -0.004 & -0.001 & 0.001 & 0.000 & $-0.005^{*}$ & -0.003 & -0.002 & 0.000 & 0.001 & 0.000 & -0.003 & 0.000 \\
\hline & 0.002 & 0.26 & 0.001 & 0.10 & 0.002 & 0.52 & 0.002 & 0.12 & 0.002 & 0.07 & 0.003 & 0.10 \\
\hline Quality of Institution (ICRG) & $-0.845 * *$ & -0.697 & $-0.547 * *$ & -0.572 & -0.299 & -0.030 & $-0.880^{*}$ & -0.300 & $-0.535^{*}$ & -0.299 & -0.346 & -0.033 \\
\hline & 0.293 & 0.81 & 0.175 & 0.96 & 0.329 & 0.09 & 0.355 & 0.39 & 0.219 & 0.57 & 0.401 & 0.08 \\
\hline Democracy (Polity 2) & -0.005 & -0.001 & -0.004 & -0.001 & -0.001 & 0.000 & -0.007 & -0.001 & -0.001 & 0.000 & -0.006 & -0.001 \\
\hline & 0.007 & 0.09 & 0.004 & 0.11 & 0.007 & 0.05 & 0.007 & 0.11 & 0.005 & 0.07 & 0.008 & 0.09 \\
\hline Inflation & 0.000 & 0.000 & 0.000 & 0.000 & 0.000 & 0.000 & 0.000 & 0.000 & 0.000 & 0.000 & 0.000 & 0.000 \\
\hline & 0.000 & 0.06 & 0.000 & 0.07 & 0.000 & 0.05 & 0.000 & 0.07 & 0.000 & 0.07 & 0.000 & 0.06 \\
\hline Credit to Private Sector & -0.003 & -0.001 & 0.000 & 0.000 & -0.002 & 0.000 & $-0.007^{* *}$ & -0.008 & 0.001 & 0.000 & $-0.008^{* *}$ & -0.007 \\
\hline & 0.001 & 0.23 & 0.001 & 0.05 & 0.002 & 0.12 & 0.002 & 0.96 & 0.001 & 0.08 & 0.002 & 0.97 \\
\hline$R$-squared & 0.77 & & 0.62 & & 0.57 & & 0.71 & & 0.61 & & 0.48 & \\
\hline Observations & 384 & 384 & 384 & 384 & 384 & 384 & 313 & 313 & 313 & 313 & 313 & 313 \\
\hline Time Dummies & Yes & Yes & Yes & Yes & Yes & Yes & Yes & Yes & Yes & Yes & Yes & Yes \\
\hline
\end{tabular}

Note: For OLS regressions, standard errors are in Italic; for BMA regressions, PIPs are in italic. Statistics in bold for BMA regressions have PIPs $>=0.5$

$* 0.05<p<0.1{ }^{* *} 0.01<p<0.05^{* * *} p<0.01$ 
Table 4. Baseline Specification, EMDEs - Commodity and Diversified Exporters

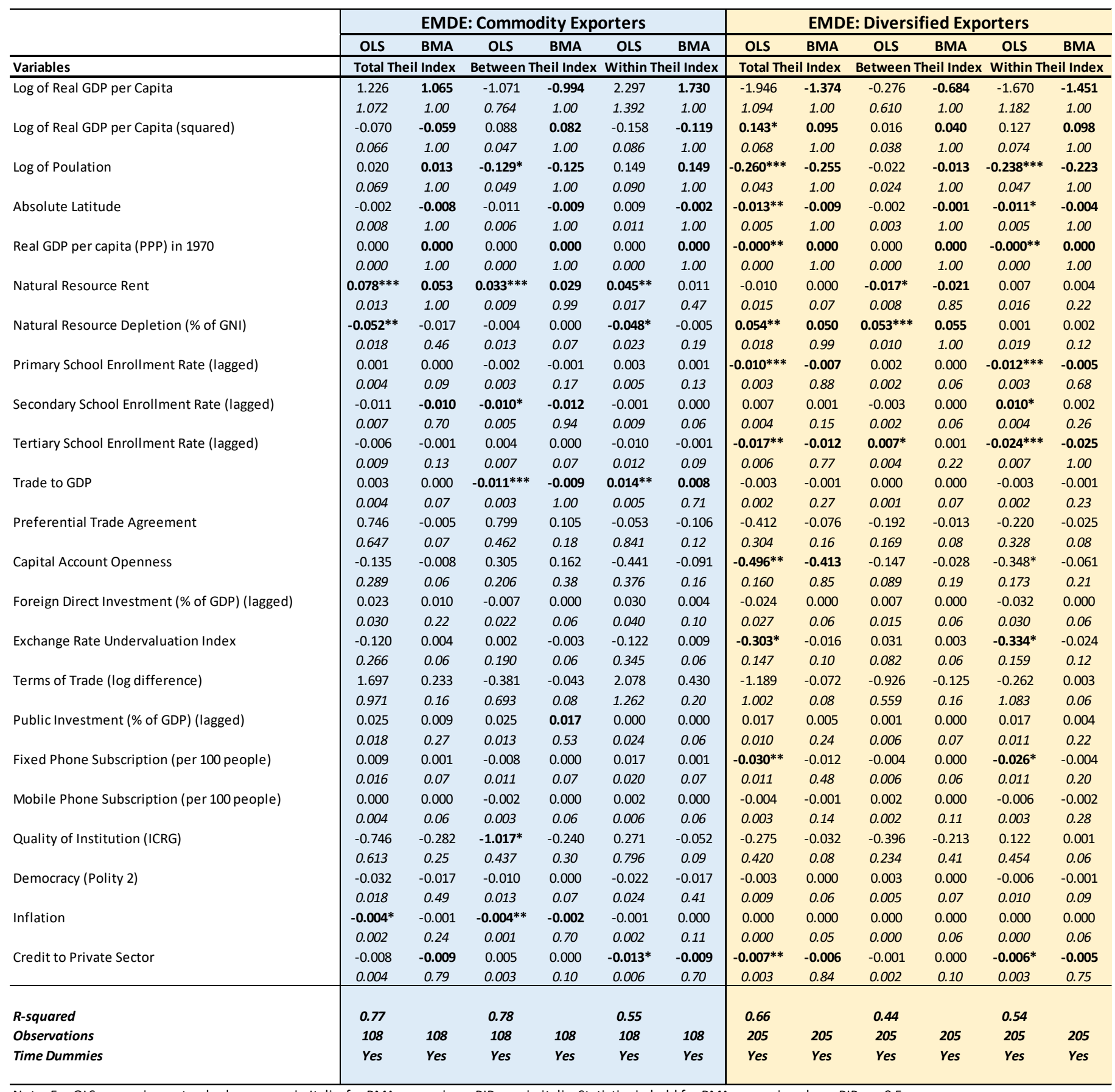

Note: For OLS regressions, standard errors are in Italic; for BMA regressions, PIPs are in italic. Statistics in bold for BMA regressions have PIPs $>=0.5$

$* 0.05<p<0.1 * * 0.01<p<0.05^{* * *} p<0.01$ 
Table 5. Baseline Specification with Doing Business Indicators

\begin{tabular}{|c|c|c|c|c|c|c|c|c|c|c|c|c|}
\hline & \multicolumn{6}{|c|}{ All Countries: Full Sample } & \multicolumn{6}{|c|}{ EMDE: Full Sample } \\
\hline & OLS & BMA & OLS & BMA & OLS & BMA & OLS & BMA & OLS & BMA & OLS & BMA \\
\hline Variables & \multicolumn{2}{|c|}{ Total Theil Index } & \multicolumn{2}{|c|}{ Between Theil Index } & \multicolumn{2}{|c|}{ Within Theil Index } & \multicolumn{2}{|c|}{ Total Theil Index } & \multicolumn{2}{|c|}{ Between Theil Index } & \multicolumn{2}{|c|}{ Within Theil Index } \\
\hline Log of Real GDP per Capita & 1.708 & -0.428 & $-1.405^{*}$ & -0.936 & 3.113* & 0.594 & 1.826 & 0.922 & $-1.735^{*}$ & -1.629 & $3.560^{*}$ & 2.441 \\
\hline & 1.203 & 1.00 & 0.592 & 1.00 & 1.347 & 1.00 & 1.350 & 1.00 & 0.710 & 1.00 & 1.545 & 1.00 \\
\hline Log of Real GDP per Capita (squared) & -0.081 & 0.038 & $0.096^{* *}$ & 0.065 & $-0.178^{*}$ & -0.027 & -0.089 & -0.036 & $0.116^{* *}$ & 0.108 & $-0.205^{*}$ & -0.134 \\
\hline & 0.073 & 1.00 & 0.036 & 1.00 & 0.081 & 1.00 & 0.082 & 1.00 & 0.043 & 1.00 & 0.094 & 1.00 \\
\hline Log of Poulation & $-0.240 * * *$ & -0.234 & -0.028 & -0.011 & $-0.213^{* *}$ & -0.215 & $-0.223^{* *}$ & -0.216 & -0.023 & 0.020 & $-0.200 *$ & -0.221 \\
\hline & 0.057 & 1.00 & 0.028 & 1.00 & 0.064 & 1.00 & 0.072 & 1.00 & 0.038 & 1.00 & 0.082 & 1.00 \\
\hline Absolute Latitude & $-0.018^{*}$ & -0.018 & $-0.013^{* * *}$ & -0.009 & -0.005 & -0.007 & $-0.018^{*}$ & -0.016 & $-0.014^{* *}$ & -0.008 & -0.005 & -0.003 \\
\hline & 0.007 & 1.00 & 0.004 & 1.00 & 0.008 & 1.00 & 0.009 & 1.00 & 0.005 & 1.00 & 0.010 & 1.00 \\
\hline Real GDP per capita (PPP) in 1970 & 0.000 & 0.000 & 0.000 & 0.000 & 0.000 & 0.000 & 0.000 & 0.000 & 0.000 & 0.000 & 0.000 & 0.000 \\
\hline & 0.000 & 1.00 & 0.000 & 1.00 & 0.000 & 1.00 & 0.000 & 1.00 & 0.000 & 1.00 & 0.000 & 1.00 \\
\hline Natural Resource Rent & $0.087^{* * *}$ & 0.083 & $0.031^{* * *}$ & 0.027 & $0.057^{* *}$ & 0.008 & $0.080^{* * *}$ & 0.084 & $0.028^{* *}$ & 0.024 & $0.052^{*}$ & 0.014 \\
\hline & 0.016 & 1.00 & 0.008 & 1.00 & 0.018 & 0.24 & 0.017 & 1.00 & 0.009 & 1.00 & 0.020 & 0.30 \\
\hline Natural Resource Depletion (\% of GNI) & $-0.072^{* * *}$ & -0.066 & -0.008 & -0.001 & $-0.064^{* *}$ & -0.008 & $-0.070^{* *}$ & -0.073 & -0.001 & 0.000 & $-0.069 *$ & -0.015 \\
\hline & 0.020 & 0.97 & 0.010 & 0.10 & 0.023 & 0.17 & 0.023 & 0.98 & 0.012 & 0.05 & 0.026 & 0.26 \\
\hline Primary School Enrollment Rate (lagged) & $-0.010^{*}$ & -0.001 & -0.003 & -0.002 & -0.007 & 0.000 & -0.010 & -0.001 & -0.001 & -0.001 & -0.008 & 0.000 \\
\hline & 0.004 & 0.19 & 0.002 & 0.38 & 0.005 & 0.04 & 0.005 & 0.16 & 0.003 & 0.14 & 0.006 & 0.05 \\
\hline Secondary School Enrollment Rate (lagged) & -0.003 & -0.001 & -0.005 & -0.001 & 0.001 & 0.000 & 0.006 & 0.000 & $-0.008^{*}$ & -0.003 & 0.014 & 0.000 \\
\hline & 0.005 & 0.13 & 0.003 & 0.18 & 0.006 & 0.04 & 0.007 & 0.06 & 0.004 & 0.45 & 0.008 & 0.04 \\
\hline Tertiary School Enrollment Rate (lagged) & -0.004 & -0.003 & 0.005 & 0.000 & -0.008 & -0.005 & -0.009 & -0.008 & 0.006 & 0.000 & -0.015 & -0.008 \\
\hline & 0.005 & 0.27 & 0.003 & 0.07 & 0.006 & 0.40 & 0.008 & 0.53 & 0.004 & 0.06 & 0.009 & 0.47 \\
\hline Trade to GDP & 0.001 & 0.000 & $-0.003^{*}$ & -0.002 & 0.004 & 0.000 & 0.000 & 0.000 & $-0.005^{* *}$ & -0.001 & 0.005 & 0.000 \\
\hline & 0.002 & 0.04 & 0.001 & 0.58 & 0.003 & 0.05 & 0.004 & 0.06 & 0.002 & 0.26 & 0.004 & 0.04 \\
\hline Preferential Trade Agreement & 0.090 & -0.004 & -0.074 & 0.002 & 0.163 & -0.003 & -0.348 & -0.014 & -0.348 & -0.009 & 0.000 & -0.002 \\
\hline & 0.390 & 0.04 & 0.192 & 0.04 & 0.436 & 0.04 & 0.565 & 0.05 & 0.297 & 0.05 & 0.647 & 0.04 \\
\hline Capital Account Openness & $-0.550^{*}$ & -0.699 & -0.083 & -0.005 & -0.468 & -0.642 & -0.408 & -0.268 & -0.086 & -0.003 & -0.322 & -0.208 \\
\hline & 0.231 & 0.94 & 0.114 & 0.06 & 0.259 & 0.85 & 0.262 & 0.46 & 0.138 & 0.05 & 0.300 & 0.34 \\
\hline Foreign Direct Investment (\% of GDP) (lagged) & 0.028 & 0.007 & -0.010 & -0.001 & 0.037 & 0.006 & 0.018 & 0.005 & -0.016 & 0.000 & 0.034 & 0.007 \\
\hline & 0.023 & 0.18 & 0.012 & 0.07 & 0.026 & 0.15 & 0.033 & 0.11 & 0.017 & 0.04 & 0.037 & 0.13 \\
\hline Exchange Rate Undervaluation Index & -0.263 & -0.012 & 0.120 & 0.026 & -0.383 & -0.012 & -0.426 & -0.027 & 0.202 & 0.004 & -0.629 & -0.017 \\
\hline & 0.293 & 0.06 & 0.144 & 0.14 & 0.328 & 0.06 & 0.353 & 0.08 & 0.186 & 0.04 & 0.404 & 0.06 \\
\hline Terms of Trade (log difference) & 2.309 & 0.419 & -0.516 & 0.001 & 2.825 & 0.766 & 1.599 & 0.290 & -1.040 & -0.009 & 2.639 & 0.942 \\
\hline & 1.617 & 0.16 & 0.796 & 0.04 & 1.811 & 0.23 & 1.762 & 0.12 & 0.927 & 0.04 & 2.017 & 0.25 \\
\hline Public Investment (\% of GDP) (lagged) & 0.043 & 0.013 & 0.001 & 0.000 & 0.041 & 0.011 & 0.036 & 0.008 & 0.002 & 0.000 & 0.035 & 0.011 \\
\hline & 0.023 & 0.29 & 0.011 & 0.04 & 0.026 & 0.23 & 0.027 & 0.20 & 0.014 & 0.04 & 0.030 & 0.21 \\
\hline Fixed Phone Subscription (per 100 people) & 0.003 & 0.000 & -0.007 & -0.003 & 0.010 & 0.000 & -0.013 & -0.002 & -0.005 & 0.000 & -0.007 & -0.001 \\
\hline & 0.010 & 0.04 & 0.005 & 0.40 & 0.011 & 0.04 & 0.015 & 0.11 & 0.008 & 0.06 & 0.017 & 0.05 \\
\hline Mobile Phone Subscription (per 100 people) & -0.002 & 0.000 & 0.000 & 0.000 & -0.002 & 0.000 & 0.000 & 0.000 & 0.002 & 0.000 & -0.002 & 0.000 \\
\hline & 0.003 & 0.10 & 0.002 & 0.05 & 0.004 & 0.08 & 0.004 & 0.04 & 0.002 & 0.05 & 0.005 & 0.04 \\
\hline Quality of Institution (ICRG) & 0.606 & 0.145 & 0.273 & -0.004 & 0.334 & 0.064 & 0.763 & 0.027 & 0.188 & 0.001 & 0.575 & 0.022 \\
\hline & 0.710 & 0.14 & 0.350 & 0.04 & 0.795 & 0.08 & 0.849 & 0.05 & 0.446 & 0.04 & 0.971 & 0.04 \\
\hline Democracy (Polity 2) & 0.008 & 0.000 & -0.002 & 0.000 & 0.009 & 0.000 & 0.012 & 0.001 & 0.010 & 0.000 & 0.001 & 0.000 \\
\hline & 0.016 & 0.04 & 0.008 & 0.06 & 0.018 & 0.05 & 0.020 & 0.06 & 0.011 & 0.04 & 0.023 & 0.05 \\
\hline Inflation & 0.012 & 0.001 & -0.005 & 0.000 & 0.018 & 0.005 & 0.012 & 0.001 & -0.003 & -0.001 & 0.015 & 0.005 \\
\hline & 0.015 & 0.06 & 0.007 & 0.07 & 0.017 & 0.18 & 0.016 & 0.06 & 0.009 & 0.08 & 0.019 & 0.17 \\
\hline Credit to Private Sector & -0.003 & 0.000 & -0.001 & 0.000 & -0.002 & 0.000 & -0.005 & -0.001 & 0.001 & 0.000 & -0.006 & 0.000 \\
\hline & 0.003 & 0.05 & 0.001 & 0.08 & 0.003 & 0.04 & 0.004 & 0.21 & 0.002 & 0.04 & 0.005 & 0.07 \\
\hline Starting a Business - DTF & 0.005 & 0.000 & 0.002 & 0.000 & 0.004 & 0.000 & 0.009 & 0.000 & 0.001 & 0.000 & 0.008 & 0.000 \\
\hline & 0.006 & 0.05 & 0.003 & 0.04 & 0.006 & 0.04 & 0.006 & 0.05 & 0.003 & 0.04 & 0.007 & 0.04 \\
\hline Dealing with Construction Permits - DTF & 0.003 & 0.000 & -0.002 & 0.000 & 0.005 & 0.000 & 0.000 & 0.000 & 0.000 & 0.000 & 0.001 & 0.000 \\
\hline & 0.005 & 0.04 & 0.002 & 0.06 & 0.005 & 0.05 & 0.006 & 0.04 & 0.003 & 0.05 & 0.007 & 0.04 \\
\hline Registering Property - DTF & -0.001 & 0.000 & -0.002 & 0.000 & 0.000 & 0.000 & 0.004 & 0.000 & -0.002 & -0.001 & 0.007 & 0.000 \\
\hline & 0.005 & 0.06 & 0.003 & 0.07 & 0.006 & 0.04 & 0.007 & 0.04 & 0.004 & 0.14 & 0.008 & 0.05 \\
\hline Getting Credit - DTF & -0.003 & -0.001 & -0.002 & 0.000 & -0.001 & -0.001 & -0.011 & -0.010 & -0.005 & 0.000 & -0.006 & -0.005 \\
\hline & 0.004 & 0.13 & 0.002 & 0.06 & 0.005 & 0.09 & 0.006 & 0.74 & 0.003 & 0.08 & 0.006 & 0.40 \\
\hline Protecting Minority Investors - DTF & 0.001 & 0.000 & 0.000 & 0.000 & 0.001 & 0.000 & -0.002 & 0.000 & -0.002 & 0.000 & 0.000 & 0.000 \\
\hline & 0.006 & 0.04 & 0.003 & 0.04 & 0.006 & 0.04 & 0.007 & 0.04 & 0.004 & 0.05 & 0.008 & 0.04 \\
\hline Paying Taxes - DTF & 0.006 & 0.001 & 0.000 & 0.000 & 0.006 & 0.001 & 0.001 & 0.000 & 0.001 & 0.000 & 0.000 & 0.000 \\
\hline & 0.005 & 0.11 & 0.003 & 0.05 & 0.006 & 0.15 & 0.006 & 0.05 & 0.003 & 0.05 & 0.007 & 0.05 \\
\hline Trading across Borders - DTF & $-0.018^{* *}$ & -0.021 & 0.005 & 0.002 & $-0.023^{* * *}$ & -0.028 & $-0.020^{* * *}$ & -0.023 & 0.005 & 0.001 & $-0.025^{* * *}$ & -0.031 \\
\hline & 0.006 & 1.00 & 0.003 & 0.36 & 0.006 & 1.00 & 0.006 & 1.00 & 0.003 & 0.23 & 0.007 & 1.00 \\
\hline Enforcing Contracts - DTF & $-0.013^{*}$ & -0.004 & 0.005 & 0.000 & $-0.018^{*}$ & -0.002 & -0.016 & -0.006 & 0.006 & 0.000 & $-0.021^{*}$ & -0.011 \\
\hline & 0.007 & 0.30 & 0.003 & 0.05 & 0.007 & 0.19 & 0.008 & 0.36 & 0.004 & 0.05 & 0.009 & 0.49 \\
\hline Resolving Insolvency - DTF & 0.003 & 0.000 & -0.002 & 0.000 & 0.006 & 0.000 & 0.000 & 0.000 & -0.001 & 0.000 & 0.001 & 0.000 \\
\hline & 0.004 & 0.08 & 0.002 & 0.09 & 0.005 & 0.05 & 0.006 & 0.04 & 0.003 & 0.05 & 0.006 & 0.05 \\
\hline R-squared & 0.83 & & 0.72 & & 0.73 & & 0.83 & & 0.73 & & 0.72 & \\
\hline Observations & 130 & 130 & 130 & 130 & 130 & 130 & 103 & 103 & 103 & 103 & 103 & 103 \\
\hline Time Dummies & Yes & Yes & Yes & Yes & Yes & Yes & Yes & Yes & Yes & Yes & Yes & Yes \\
\hline
\end{tabular}

Note: For OLS regressions, standard errors are in Italic; for BMA regressions, PIPs are in italic. Statistics in bold for BMA regressions have PIPs $>=0.5$

$* 0.05<p<0.1 * * 0.01<p<0.05 * * * p<0.01$ 